\title{
MULTIPLE BLEND SUPPLEMENTRY CEMENTITIOUS MATERIALS (RECOVERED MINERAL COMPONENTS), BENEFIT SUSTAINABILITY THROUGH INNOVATIVE CONCRETE DESIGN
}

\author{
Eckart R. Bühler \& Robert C. Lewis
}

Eckart R. Bühler is the Engineering Services Manager at Norchem, Inc., USA.

Robert C. Lewis is the Technical Marketing Manager - Silica Fume, for Ferroglobe PLC.

\begin{abstract}
Supplementary Cementitious Materials (SCMs) have been utilized in commercial concrete production around the world for over three decades with ample project track record. While initially understood as cement replacements, often merely to improve concrete economy, these materials have developed into Sustainability design tools, extending the structural concrete Life Cycle, improving Resilience and substituting for Portland cement, thus reducing the Carbon Footprint of concrete.

The U.S. Environmental Protection Agency has recently re-designated Fly Ash, Slag Cement \& Silica Fume as Recovered Mineral Components (RMCs) that increase concrete Strength and Durability; Utilization of RMCs reduces the amount of these materials that would otherwise be designated as waste and landfilled.

Silica Fume is one of the smallest particles incorporated into concrete and its effect on concrete Rheology has been evident, when used in shotcrete, for some time. This has been exploited in Self Consolidating Concrete as well as Ultra High-Performance Concrete. The synergistic effect of combining silica fume and other SCMs into ternary or quaternary concrete mix designs has been shown to provide unique solutions to in-field challenges of high-performance concrete applications.
\end{abstract}

Keywords: Recovered Mineral Components, Supplementary Cementitious Materials, Sustainability, Life Cycle, Resilience, Carbon Footprint, Rheology, Self-Consolidating Concrete, Ultra High-Performance Concrete, Fly Ash, Slag Cement, Silica Fume

\section{INTRODUCTION}

In the United States, the Environmental Protection Agency (EPA) has updated the designation of Supplementary Cementitious Material (SCM), for sustainability language, to Recovered Mineral Component (RMC). Three RMCs, fly ash, slag cement and silica fume are designated as meeting the requirements of the Resource Conservation \& Recovery Act (RCRA) when included in a concrete mix design. RMCs are pre-consumer waste materials, originating from mineral conversion industries that initially had been land-filled until their beneficial characteristics to concrete were discovered and applied. What differentiates RMC 
from SCM is that RMC utilization directly eliminates landfill storage of waste materials. In 2008 a report to Congress [EPA 530-R-08-007] identified the positive environmental impacts per metric ton of RMC substituted for ordinary Portland cement (OPC), as listed in Table 1. These impacts are also presented per pound, or kilogram, of utilization for each of the three EPA-designated RMCs in Table 2, as well as their contribution of carbon footprint in kilograms per metric ton, as compared to OPC. In Europe, and the UK, the term SCM is more commonly used.

\section{RHEOLOGY}

The concrete utilized for some of the vertical elements in the construction of 1 World Trade Center in New York City is a recent example that combined all three of the RMCs together with OPC in one novel concrete mix design. The concrete's total binder content of "only" $837 \mathrm{lbs} / \mathrm{yd}^{3}\left(518 \mathrm{~kg} / \mathrm{m}^{3}\right)$, which yielded average compressive strengths exceeding 16,000 psi $(110 \mathrm{MPa})$, was proportioned as $55 \%$ slag cement, $35 \%$ OPC, $7 \%$ fly ash and $3 \%$ silica fume. Despite a very low water to total-cementitious-binder ratio (W/B) of 0.25 , the concrete was produced and delivered to the project site as Self-Consolidating Concrete (SCC). The silica fume, at its low inclusion rate of $3 \%$ of all binder materials, probably contributed more to the rheology in this concrete, than to the high ultimate compressive strength. This strength showed a very high binder efficiency of $18.5 \mathrm{psi} / \mathrm{lb}(0.2 \mathrm{MPa} / \mathrm{kg})$. In comparison, an average $\mathrm{f}^{\prime} \mathrm{c}=4,000 \mathrm{psi}(28 \mathrm{MPa})$ conventional concrete mix design, with an average $500 \mathrm{lbs} / \mathrm{yd}^{3}$ (297 $\left.\mathrm{kg} / \mathrm{m}^{3}\right)$ of OPC, has a binder efficiency of $9 \mathrm{psi} / \mathrm{lb}(0.1 \mathrm{MPa} / \mathrm{kg})$. Such a mix would yield a carbon footprint of approximately $230 \mathrm{~kg} / \mathrm{yd}^{3}\left(300 \mathrm{~kg} / \mathrm{m}^{3}\right)$, of which $95 \%$ is due to the OPC. The utilization of three RMCs in the $\mathrm{f}^{\prime} \mathrm{c}=14,000 \mathrm{psi}(96 \mathrm{MPa})$ designed concrete on 1 World Trade Center, reduced the OPC quantity by approximately two-thirds of the total binder content, and afforded a significantly lower carbon footprint of $168 \mathrm{~kg} / \mathrm{yd}^{3}\left(218 \mathrm{~kg} / \mathrm{m}^{3}\right)$.

As in the before mentioned project, where a quaternary mix design was used, it has become modern practice to combine various RMCs, not only to achieve a lowest possible carbon footprint but also to take advantage of the synergies between them that impart desirable engineering properties. In the plastic state, inclusion of silica fume alongside fly ash or slag cement can offset delayed setting time and boost early strength gain. The water demand of silica fume that can occur at high dosages, can be offset when used in lower dosages and in combination with fly ash or slag, as shown in these tables. 

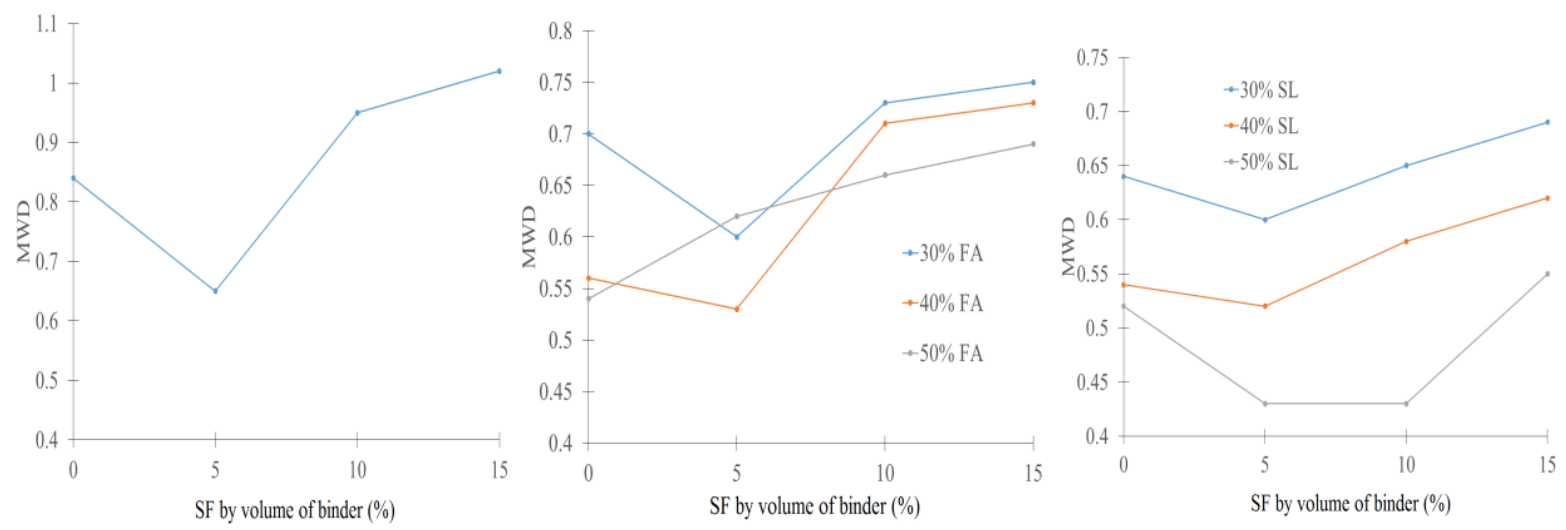

Compared to common concrete ingredients, silica fume is a very small particle size, with a high specific surface area, having rheological attributes that increase yield stress and plastic viscosity, and requires additional lubricant to maintain a desirable workability level. Conversely, silica fume's packing density characteristics decrease yield stress and plastic viscosity, depending on the synergy between other concrete ingredients and the percentage of silica fume in the total binder content. Figure 1 demonstrates silica fume's variable effect on concrete viscosity as compared to the linear behavior of other non-aggregate ingredients. Silica fume's rheological properties enable workability-engineering for specific applications. In contrast to lowering viscosity, as in the 1 World Trade Center design, an 8-12\% silica fume inclusion in shotcrete, for example, increases mix viscosity, which is ideal for building up thicker layers with minimized rebound and slippage. Walt Disney Theme Parks of Orlando constructed the 300 foot $(100 \mathrm{~m})$ tall "Expedition Everest" feature with a specialized shotcrete mix design containing silica fume and a hydration control admixture - needed to maintain surface plasticity for several hours after application - in order for the artists to carve a realistic mountain-scape onto its surface.

\section{MILESTONES FOR CONCRETE WITH RMCs.}

While fly ash and slag cement where initially utilized for economy, as a replacement for OPC, silica fume provided concrete with enhanced mechanical properties such as compressive and flexural strength, modulus of elasticity, abrasion and impact resistance. Reduced permeability, achieved by incorporating silica fume into the concrete design, is reflected in enhanced durability in resisting chemical and sulfate attack, or mitigating alkalisilica reactivity. Benefits in concrete permeability reduction were also realized for combinations with fly ash and slag cement, at much earlier ages although, in their own right, these RMCs can achieve durability enhancement for concrete at a later stage. While this slower reactivity is utilized in specific applications such as mass concrete, it is often the early age resistance of a concrete that will determine the service life in a harsh environment, hence the addition of the faster reacting silica fume. Introduction of silica fume into widespread commercial availability in the United States began in the early 1980's, and versatile applications have evolved over the last few decades, as presented in the following selection of projects, mostly in combination with fly ash or slag cement: 


\section{3 - The Kinzua Dam Stilling Basin, Pennsylvania}

The US Army Corps of Engineers tested various aggregates to provide concrete with superior abrasion resistance when replacing the severely eroded stilling basin at the Kinzua Dam (Figure 2) in Pennsylvania. This research was to find the optimum design to resist the abrasion and erosion caused in the basin. The dam had been built in 1967 and the stilling basin floor replaced in 1974 with a pure OPC / high strength aggregate concrete. This had failed by 1983, as shown in the figure. A silica fume concrete, using local aggregates, increased the abrasion performance, as shown in the graph, by increasing both the compressive strength, specified at $\mathrm{f}^{\prime} \mathrm{c}=12,500 \mathrm{psi}(87 \mathrm{MPa})$, and the bond to the aggregate. The Kinzua Dam spilling basin rehabilitation became one of the first large scale applications of silica fume concrete in the United States, and the repair showed little wear damage in the diver's inspection in 2013. As of 2018, the repair has now lasted more than 5 times longer than the original concrete.

\section{8 - The Great Stupa of Dharmakaya, Colorado}

Before the start of this unusual project, to be built by volunteer labor over a long period of time, at an elevation above $8,500 \mathrm{ft}(2,500 \mathrm{~m})$, a surprising request for a 1000 -year concrete service life circulated the industry. Statistical analyses and novel concrete technology, with the inclusion of silica fume and synthetic air-entraining admixture into the mix design, provided such a potential, with a ternary, low water-binder ratio, high strength mix design (Figure 3). Exceptional concrete quality field control was required to maintain concrete mix characteristics, including high workability for placement, for the 90-minute transportation time. Completion of this project was in 2005 , after nearly two decades of work.

\section{0 - Bridge Deck Overlays, Ohio}

The Ohio Department of Transportation structures, located in the US 'rust-belt', have a greatly increased rate of reinforcement steel corrosion, due to the higher than average yearly freezing and thawing season. The main factor causing this is increased use of road salt to melt ice on the highways and in particular on bridges. O-DOT pioneered the specification of silica fume as part of the concrete mix design to combat this (Figure 4), alongside a "very low permeability" rating of less than 1,000 coulombs, as determined by the Rapid Chloride Permeability test AASHTO T-277.

\section{2 - Tsing Ma Bridge, Hong Kong}

The Lantau Link in Hong Kong comprises the Tsing Ma suspension bridge linking Tsing Yi to Ma Wan; viaducts crossing Ma Wan; and the Kap Shui Mun cable-stayed bridge linking Ma Wan to Lan Tau. The Tsing Ma Bridge (Figure 7) is a major Hong Kong landmark, with a main span of $4500 \mathrm{ft}$. $(1377 \mathrm{~m})$, the world's longest to carry both road and rail, and its concrete towers are $675 \mathrm{ft}$. (206 m) tall. Construction of Tsing Ma Bridge began in May 1992 and was completed in May 1997. Other statistics for this bridge include: a total length of $7200 \mathrm{ft}$. (2200 m); shipping clearance of $203 \mathrm{ft}$. (62 m); and a volume of concrete of 650,000 $\mathrm{yd}^{3}\left(500,000 \mathrm{~m}^{3}\right)$.

The concrete used in the construction consisted of two ternary mixtures, one containing ordinary Portland cement (OPC), ground granulated Blastfurnace slag (ggbs) and silica fume, 
the other containing OPC, fly ash and silica fume. The OPC, ggbs and silica fume ternary blend, used for slip-forming the towers, had a cementitious weight ratio of $30 \%$ Portland cement, to $65 \%$ slag cement and 5\% silica fume. This allowed pumpability over the distance from the production plant and the vertical height to the point of placing, and lowered the heat evolution, to reduce thermal stress and delayed ettringite formation (DEF) in the large mass concrete tower bases. The mix was also designed to give a very high resistance to chloride penetration for the marine environment. The target strength for this mix was 9,400 psi (65 $\mathrm{MPa})$, but it achieved over 11,600 psi (80 MPa) at 90 days. The OPC, fly ash, silica fume ternary blend was a ratio of $70 \%$ Portland to $25 \%$ fly ash and $5 \%$ silica fume and was used for the support columns and other elements of the bridge.

\section{3 - The Solid Waste Authority of Palm Beach County, Florida}

In this project, an alternative was sought to the customary 2" $(5 \mathrm{~cm})$ thick armored floor topping overlays that had an average service life of only two to three years, causing repetitive expensive rehabilitation and time-consuming facility shutdowns during repairs. Field research conducted on-site developed an alternative concrete design incorporating low W/C, a fly ashblended OPC along with a very high silica fume percentage for a self-leveling, one-pass finish concrete design (Figure 5). This type of concrete design gave the Solid Waste Authority a decrease of roughly $50 \%$ in construction time at approximately half of the normal expenditure for the rehabilitation of their tipping floor systems. Service life of the tipping floors has nearly tripled to seven years. Similar concrete mix designs, with high silica fume percentages of up to $20 \%$ have now found multiple applications in the refinery, processing and chemical industries.

\section{7 - Nuclear Storage Facility, Hanford}

The construction of the radioactive canister storage facility placed utmost consideration on crack control for its concrete structure, which translates into tight temperature control for this mass concrete application. (Figure 6). Engineering methods such as cooling the concrete, limiting concrete temperature at point of delivery and lowering the heat of hydration, by substituting OPC with both fly ash and silica fume, successfully provided a project-suitable high-strength mass concrete.

\section{0 - Four Seasons, Miami}

At $750 \mathrm{ft} .(230 \mathrm{~m})$ height it is the tallest structure, south of Atlanta, in the southeast USA. Designed for resisting high wind loads in 'hurricane country', dense steel reinforcement was required in the vertical structural elements. A high-strength, high modulus of elasticity and highly workable concrete mixture was designed to flow through and around the steel and give a tightly integrated unit. The $\mathrm{f}^{\prime} \mathrm{c}=10,000 \mathrm{psi}(\mathrm{MPa})$ concrete design employed a 50-50 ratio of slag cement and OPC which aided in maintaining a very low $\mathrm{W} / \mathrm{C}$ in a hot weather concreting environment, and a 5\% silica fume addition to achieve a modulus of elasticity typically not attainable with the local aggregate that was used. (Figure 8). Believed to be one of the earliest mass-produced, cast-in-place, SCC applications, the concrete was delivered yearround through the extreme hot weather season without concrete temperature restrictions. 


\section{TARGETED PERFORMANCE}

High-rise structures continue to impress not only in newly achieved heights, but in novel combinations of cement substitutes such as RMCs, to achieve both plastic and hardened performance. The mixtures must not only be to mechanical design requirements in the finished elements, but increasingly are required to have extreme distance pumpability with retention of workability.

\section{9 - The Burj Khalifa, Dubai}

An 8,700 psi (60 MPa) OPC / fly ash / silica fume ternary blend was used for the foundation piling, and a high-strength ternary mix concrete was pumped over 2,000 feet $(620 \mathrm{~m})$ in the world's tallest building, as of 2018 (Figure 9). A similar mix design is being used in the Kingdom Tower in Jeddah and for the new Dubai Tower, both vying to be the next 'World's Tallest'.

\section{4 - STEP project, Abu Dhabi}

The Strategic Tunnel Enhancement Programme (STEP) is a large diameter, gravity-driven, tunnel network, roughly doubling wastewater treatment capacity (Figure 10). 390,000 $\mathrm{yd}^{3}$ $\left(300,000 \mathrm{~m}^{3}\right)$ of concrete were used for 52 total miles $(84 \mathrm{~km})$ of tunnel, designed for high strength and impermeability. The class $\mathrm{C} 40 / 50$ concrete contained $6 \%$ silica fume and the class $\mathrm{C} 40 / 20$ was a fly ash blend with $5 \%$ silica fume with average compressive strengths exceeding 9,000 psi (60 MPa) and a very low Rapid Chloride Permeability to ASTM C1202. During construction of a similar waste water project - a pumping station in Jeddah, Saudi Arabia, the design had to ensure placement without loss of cohesion. This was for a 31,400 $\mathrm{yd}^{3}\left(24,000 \mathrm{~m}^{3}\right)$ continuous pour of SCC that underwent a drop chute placement of 230 feet (70m) and achieved this without segregation or bleeding (Figure 11).

\section{DESIGN LIFETIME}

The long-term durability of structures came into focus in the mid-to-late 1980's as it became evident that concretes with exposure to chlorides, whether by natural (vicinity of salt water) or man-made causes (de-icing salt application), seemed to have an increased rate of deterioration than observed on past structures, resulting in a decrease in service life. These phenomena could be due to decreasing the concrete cover over the structural reinforcement steel as part of the trend to produce less voluminous structures, slender and more complex in design. Less concrete cover protecting the reinforcement steel provides for easier and accelerated access for deleterious materials, such as chloride, to penetrate through concrete. Rather than sacrificing the benefits of economy, aesthetically pleasing architecture or longer spans in the structures, new corrosion-resistant concrete design initially specified silica fume and corrosion inhibitors to combat the rapid deterioration effects. This soon evolved into specifying certain durability characteristics and thus the Design-Life or Service-Life of the structure. 


\section{7 - The Confederation Bridge, New Brunswick}

This was one of the early calls for a 100-year design life for the concrete in such a construction. This 8 -mile $(13 \mathrm{~km})$ long bridge (Figure 12) would be adversely exposed to ice, rogue waves, freezing and thawing cycles, impact and abrasive forces. The bridge was constructed between 1993 and 1997 and utilized both fly ash and silica fume. This was based on the performance of a similar mix had, used a few years prior to this, on the very large Hibernia oil drilling platform, situated nearby in the Atlantic Ocean off New Brunswick, and exposed to similar environmental elements.

\section{5 - East Sea Bridge, Shanghai}

This 'twin bridge', each side three lanes, extends 20 miles $(32.5 \mathrm{~km})$ from Shanghai's Luchao Port to the new Shanghai deep-sea port (Figure 13). It was constructed in less than three years, between $26^{\text {th }}$ June 2002 and the $25^{\text {th }}$ of May 2005, using two multiple-binder blends, one ternary and the other quaternary. The bridge design had an extensive list of climatic resilience, chemical and physical resistance requirements for its 100-year service life target, including surviving a Richter 7 earthquake.

The compressive strength requirements were 5,100 psi (35 MPa) and 7,250 (50 MPa) for various applications. The two binders used in the mixture proportions were a ternary blend of Portland cement, slag cement and fly ash, and a quaternary blend of Portland cement, slag cement, fly ash and silica fume. These binders were 'pre-blended' at the cement factory allowing for only two silo capacities at each production plant (onshore and offshore), although different binder contents were used for various design elements of the bridge.

\section{7 - I-35 W Bridge, Minneapolis}

When the bridge suffered a devastating collapse, it was rebuilt within a year (Figure 14), employing concrete designs using all three RMCs. This was to satisfy stringent durability requirements and for sustainability and longevity.

\section{7 - The Panama Canal}

One of the most recent '100-year service life' design concepts was for the recently completed Third Set of Locks project (Figure 15). Here over 2.5 million $\mathrm{yd}^{3}\left(2\right.$ million $\left.\mathrm{m}^{3}\right)$ of mass concrete utilized natural pozzolan and silica fume for low permeability.

\section{ONWARD}

Ultra-High-Performance Concrete (UHPC) is concrete with compressive strength in excess of 22,000 psi (150 MPa) and with exceptional durability characteristics. With W/B at or below 0.20 , a very high silica fume content of $20-30 \%$ and no coarse aggregate, it nearly crosses the material definition from concrete into a composite. 

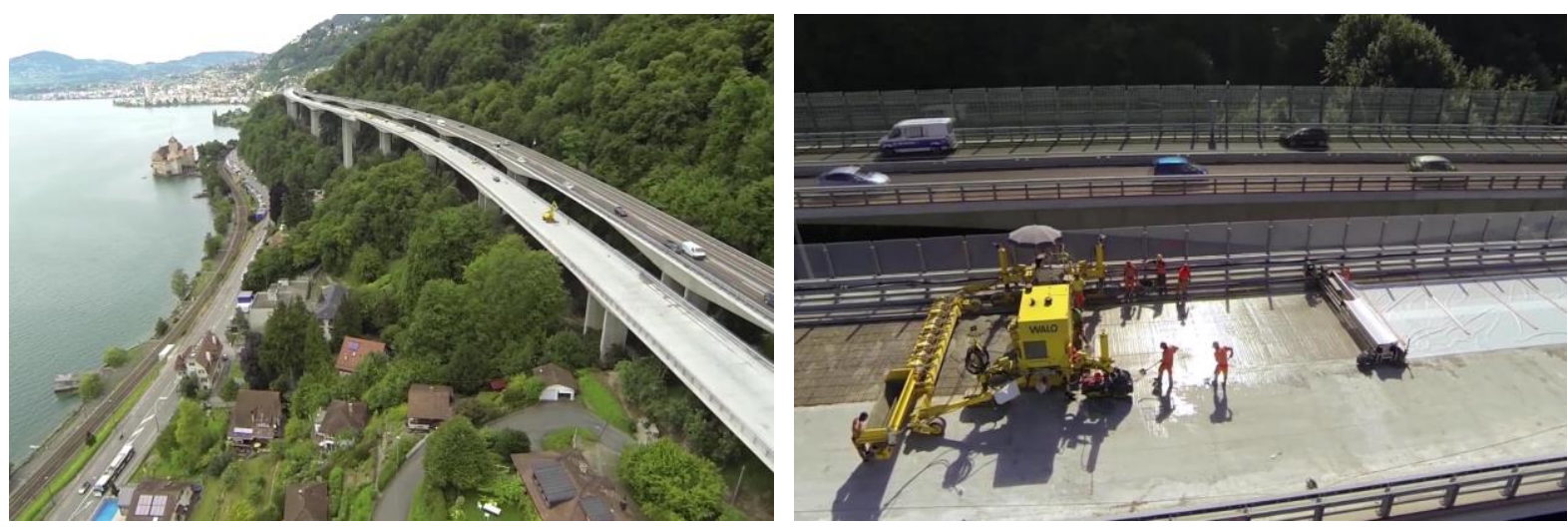

In 2014, the Viaduc Chillon in Switzerland received a 2 inch $(5 \mathrm{~cm})$ thick overlay of UHPC for a rehabilitation project where some 4,600 $\mathrm{yd}^{3}\left(3,500 \mathrm{~m}^{3}\right)$ of UHPC were placed with a modified paving machine.

\section{REFERENCES}

1.) EPA Report to Congress EPA 530-R-08-007, June 2008 "Study On Increasing the Usage of Recovered Mineral Components in Federally Funded Projects Involving Procurement of Cement or Concrete, $225 \mathrm{pp}$.

2.) Bühler, E., "Green Concrete Design Incorporating Life Cycle Assessment \& Service Life Prediction and the Effect of Lowering the Carbon Footprint with High Performance Concrete "International Concrete Sustainability Conference, May 7-10, 2012, Seattle, WA, proceedings.

3.) Schokker, Andrea, J., 2010, The Sustainable Concrete Guide, Applications, U.S. Green Concrete Council, 117 pp.

4.) Khayat, K.H., Mehdipour, I. 2014, "Design And Performance Of Crack-Free Environmentally Friendly Concrete "Crack-Free Eco-Crete”." CIES-NUTC Report at the Missouri University of Science and Technology, Rolla, MO

5.) Holland, Terrence C., April 2005, Silica Fume User's Manual, 183 pp.

6.) Nehdi, M.L., Shareef, A., Algoneid, H.K., July 2014 "Mitigating of Thermal Cracking in Massive Foundations", Concrete International, pp.38-44.

7.) Bühler, E., May 2007, "Two Decades of Ready-Mixed High Performance Silica Fume Concrete... a US Project Review” NRMCA Concrete Technology Forum, proceedings, Dallas, $22 \mathrm{pp}$.

8.) Lewis, R., “Microsilica Concrete - Optimising Durability”, Oman 20-22 ${ }^{\text {nd }}$ October 2017, Concrete for the Modern Age, pp 270 - 285. 


\section{TABLES AND FIGURES}

\section{List of Tables:}

Table 1 - Impact of Recovered Mineral Component Substituted for Portland Cement

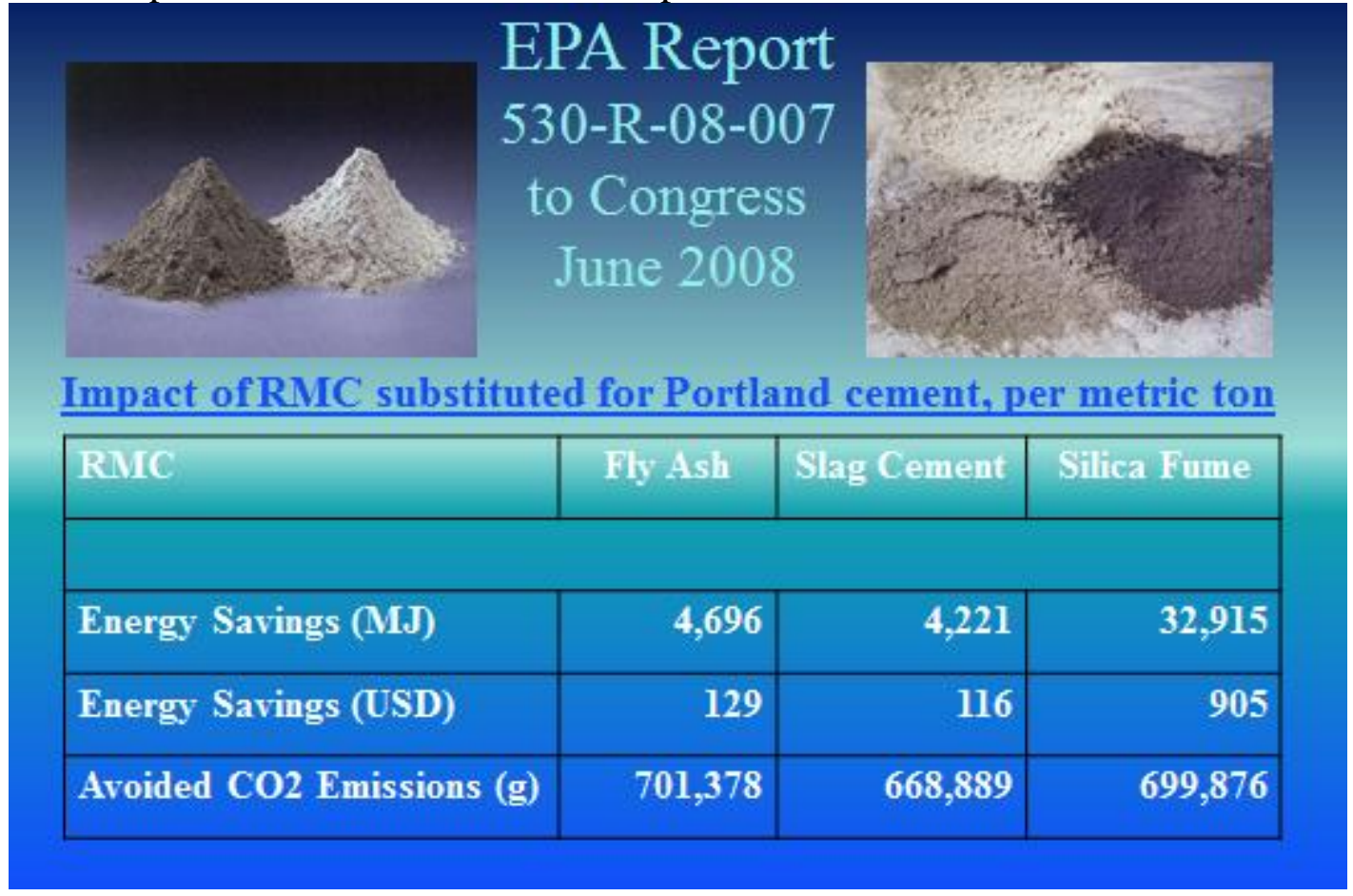

Table 2 - Environmental Impact, Energy Savings \& Carbon Footprint of RMC

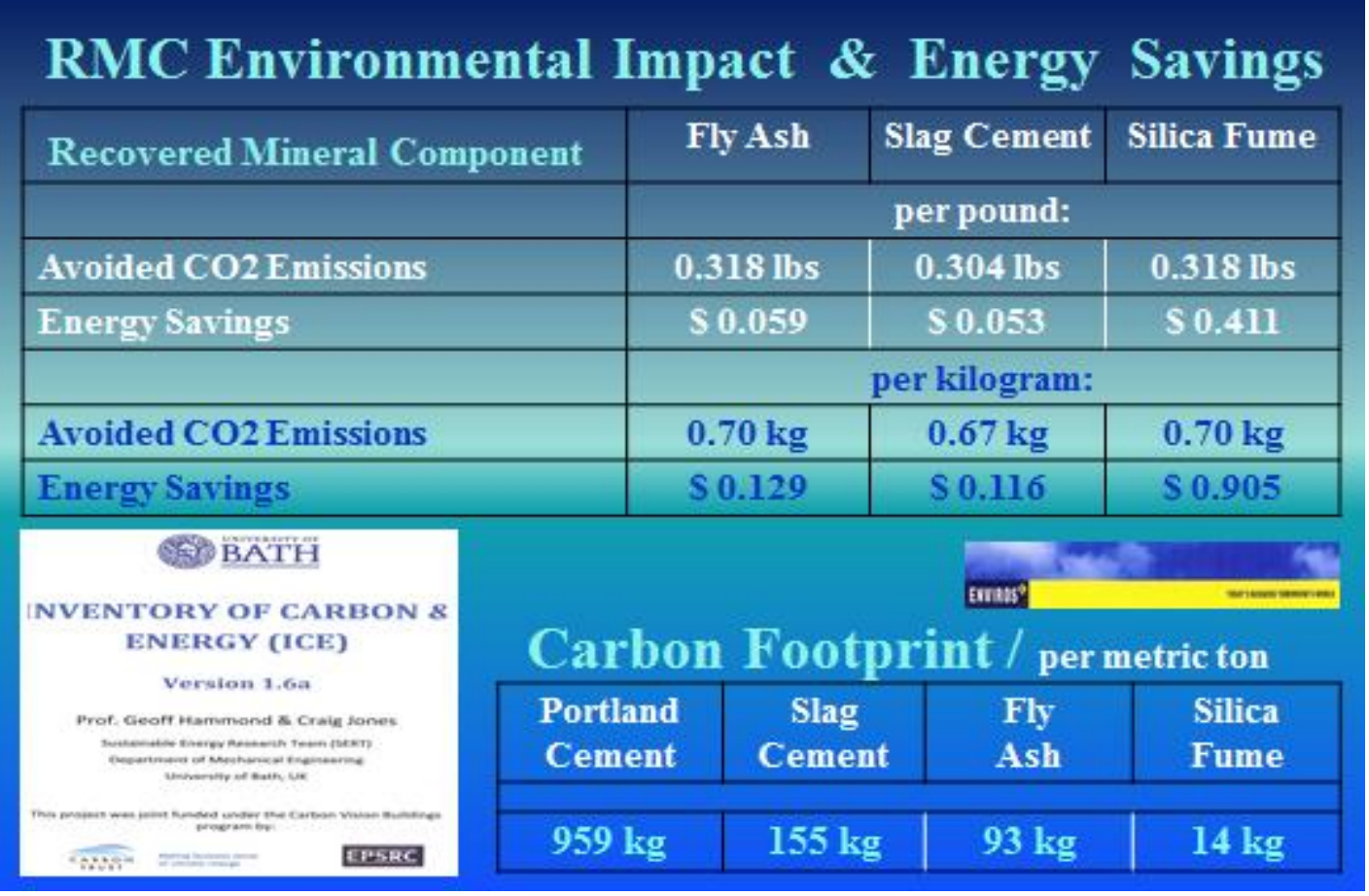




\section{List of Figures:}

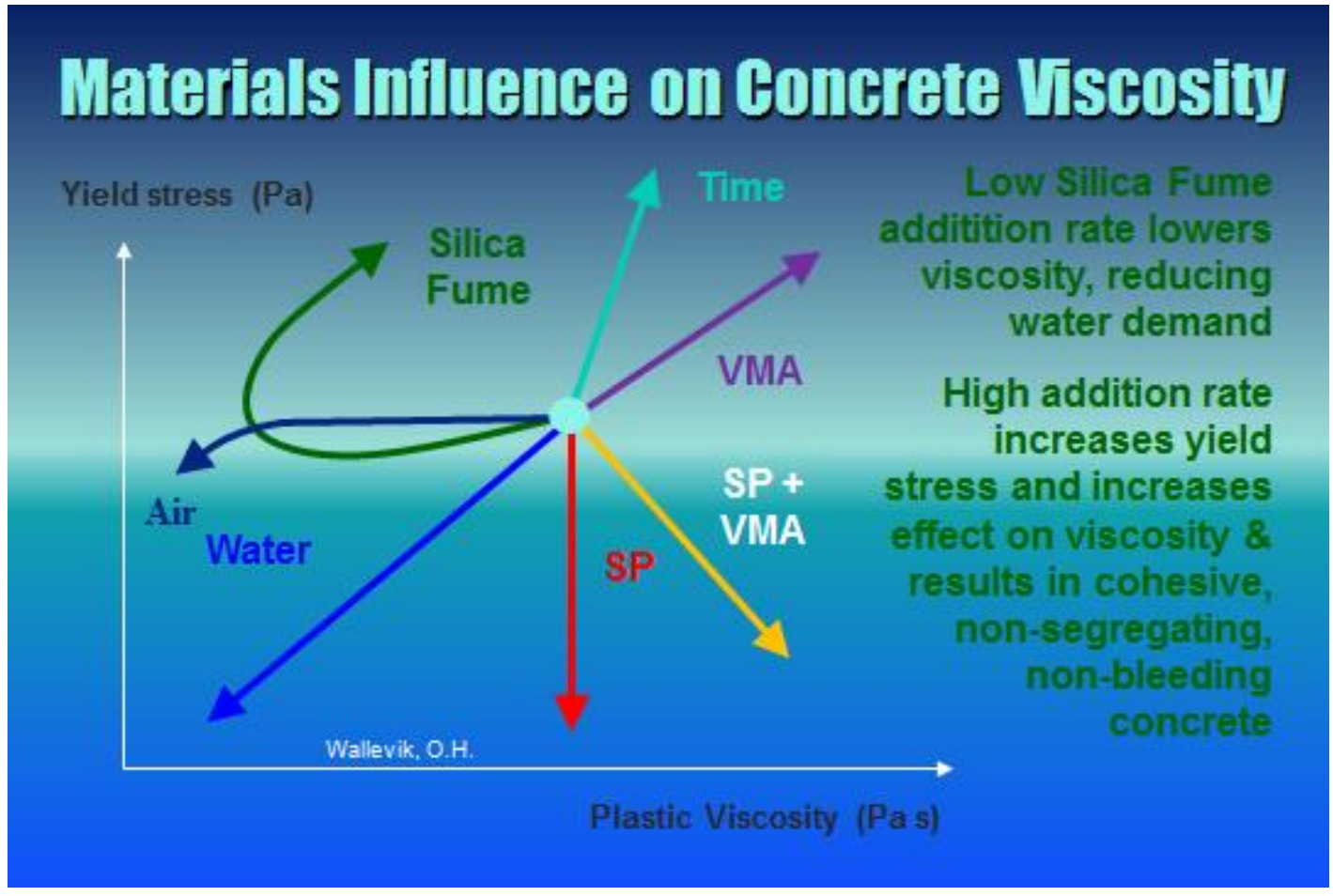

Fig. 1 - Material Influence on concrete viscosity

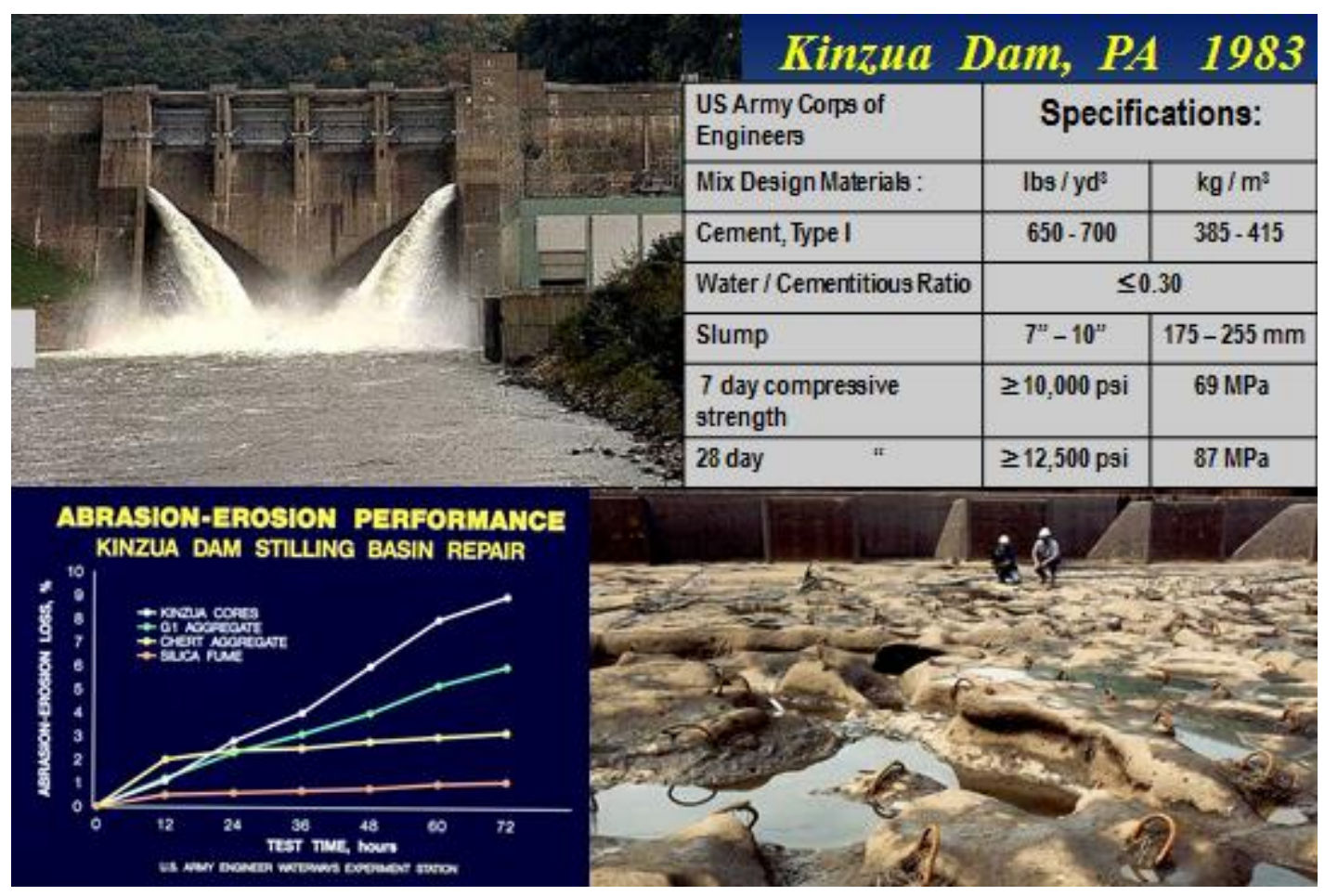

Fig. 2 - Kinzua Dam, Pennsylvania 


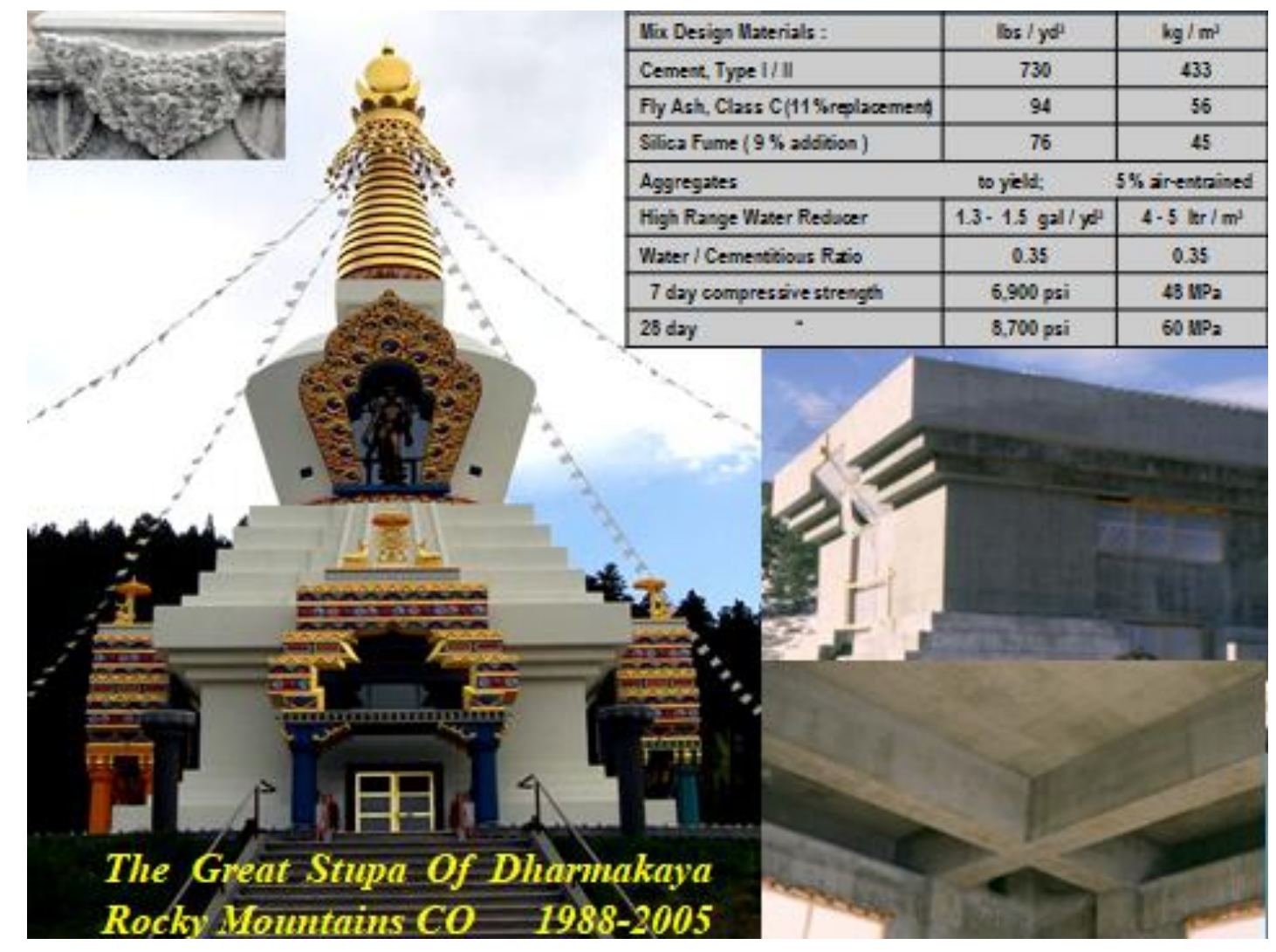

Fig.3 The Great Stupa of Dharmakaya

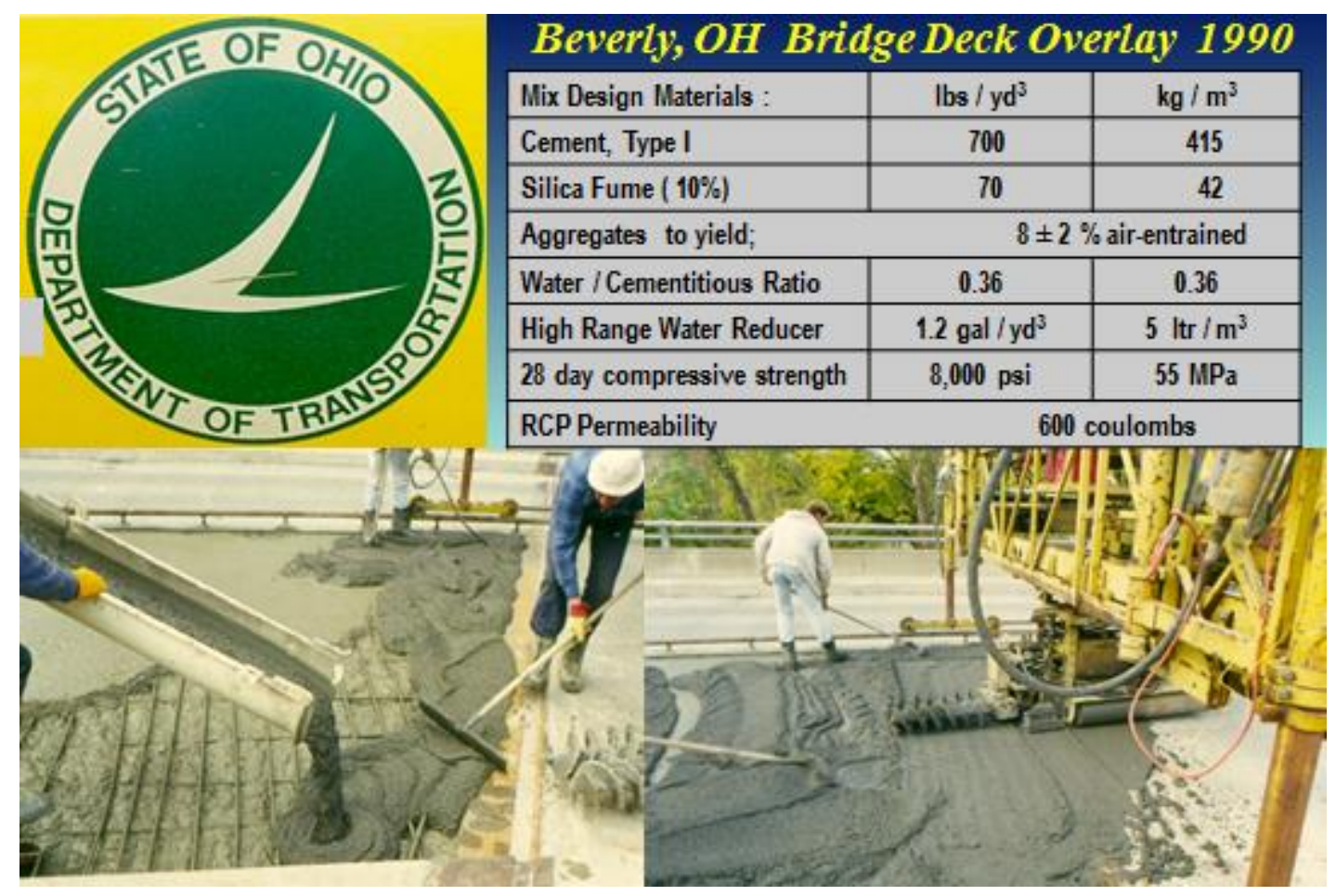

Fig. 4 - Ohio Department of Transportation 


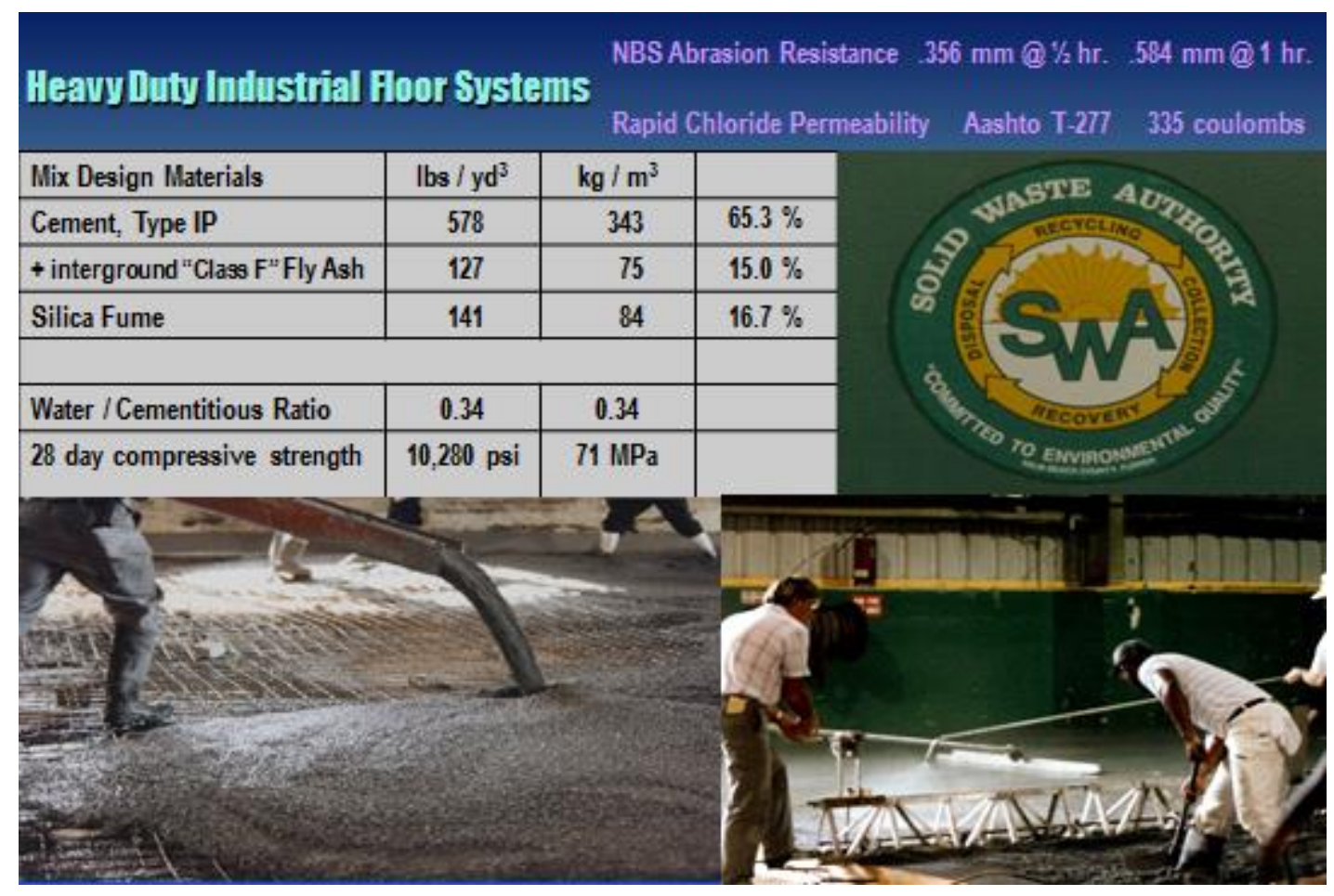

Fig. 5 - Solid Waste Authority, Palm Beach County, Florida

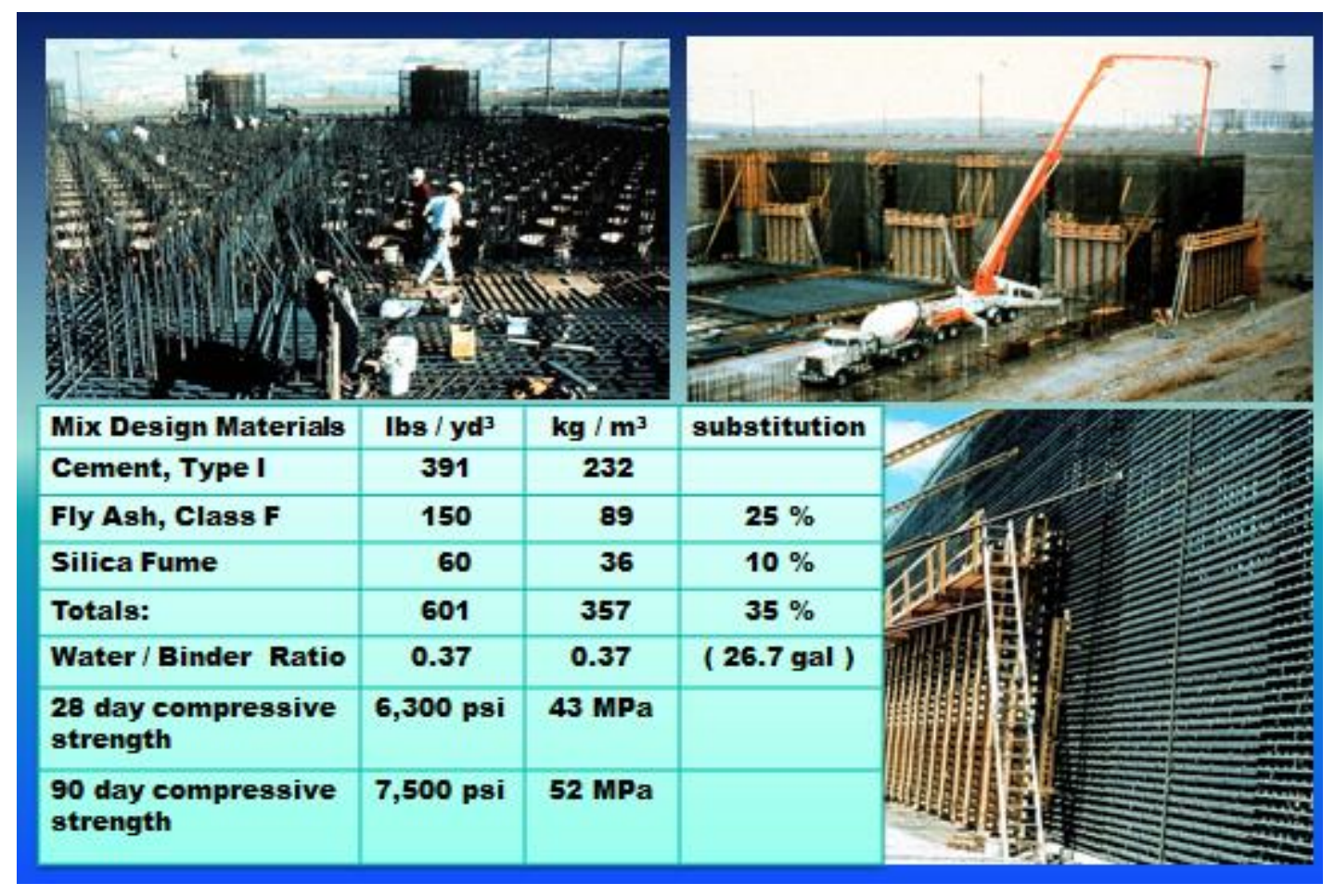

Fig. 6 - Radioactive Waste Canister Storage, Hanford, Washington 


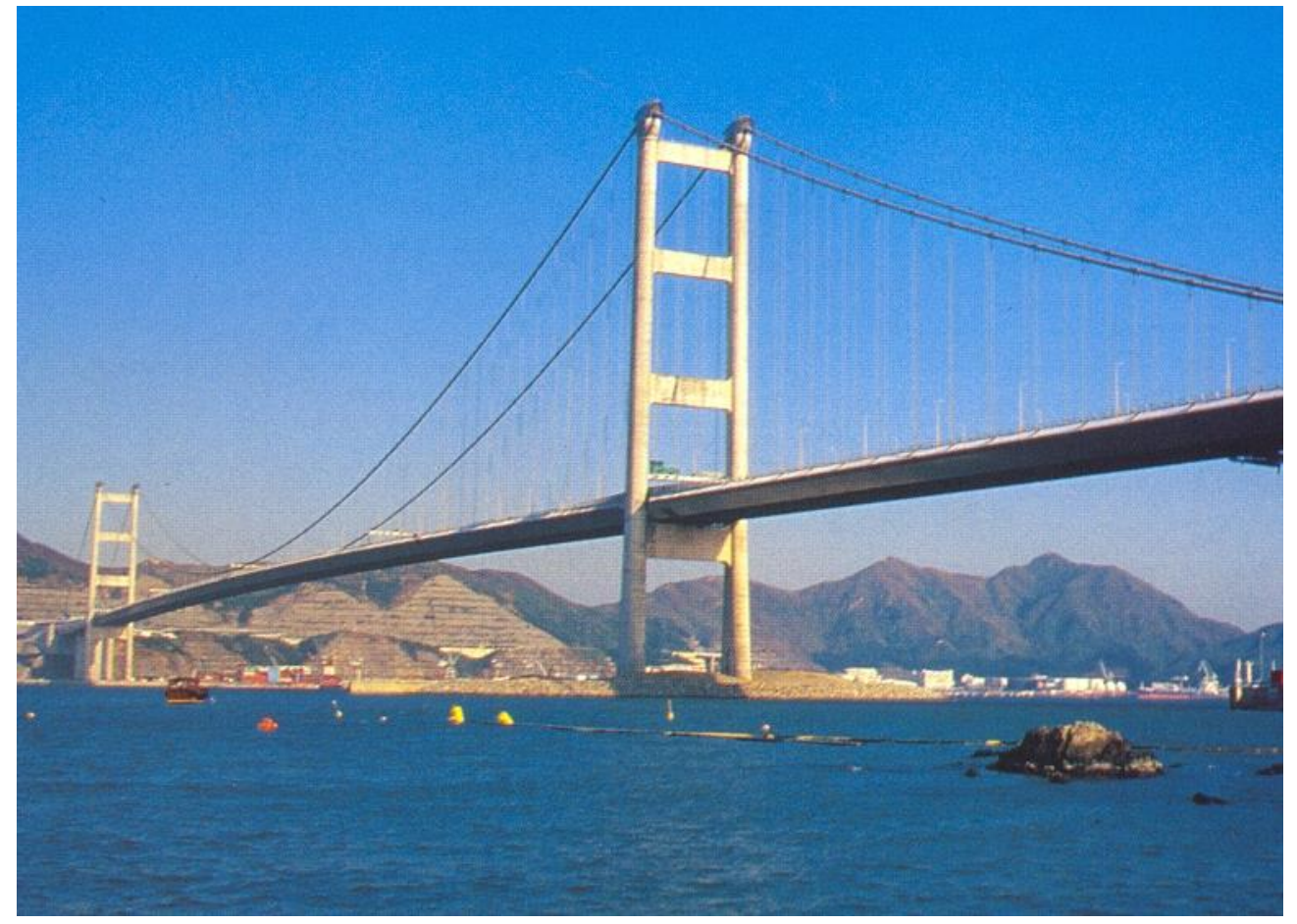

Fig 7 - Tsing Ma Bridge, Hong Kong

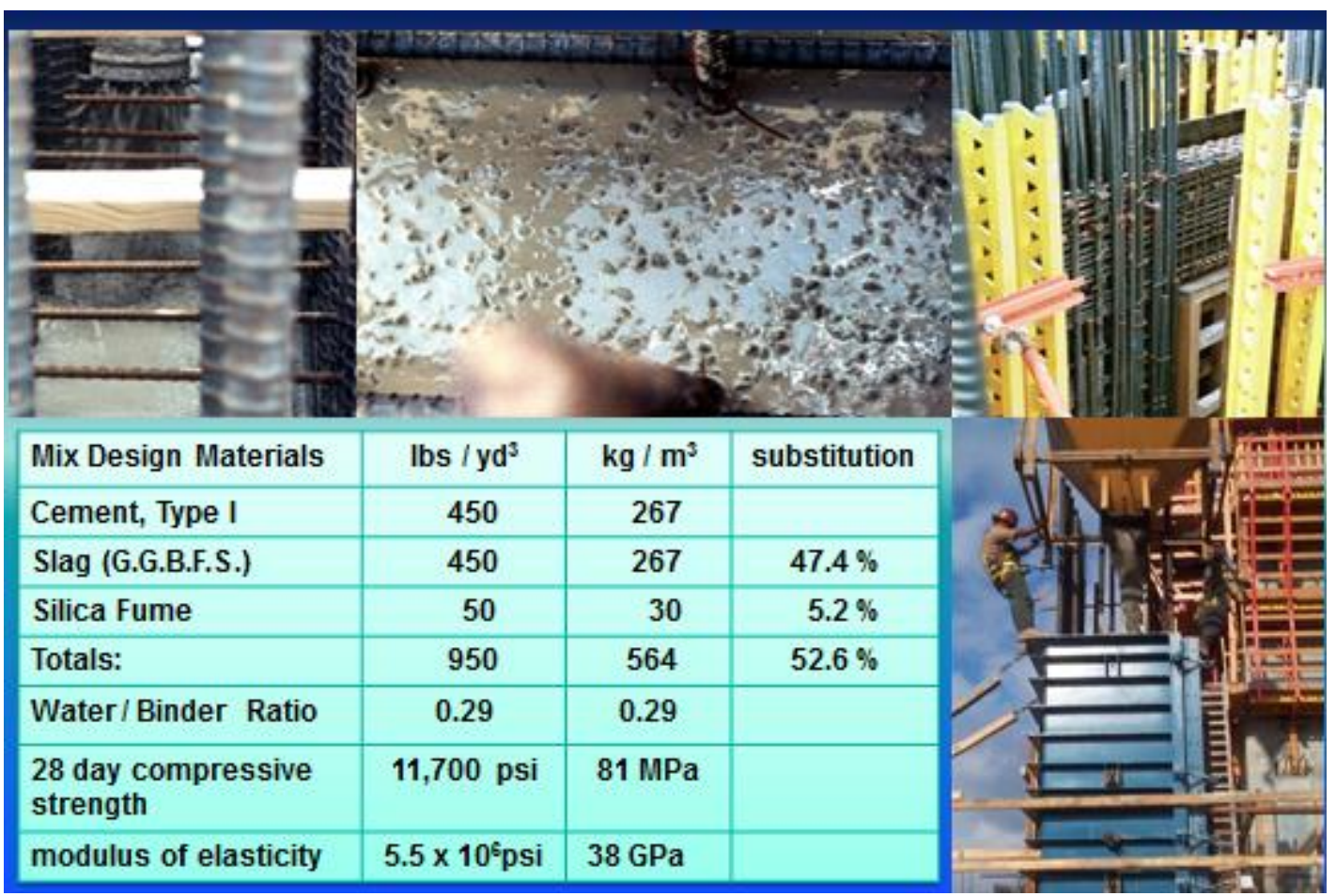

Fig. 8 - The Four Seasons, Miami, Florida 


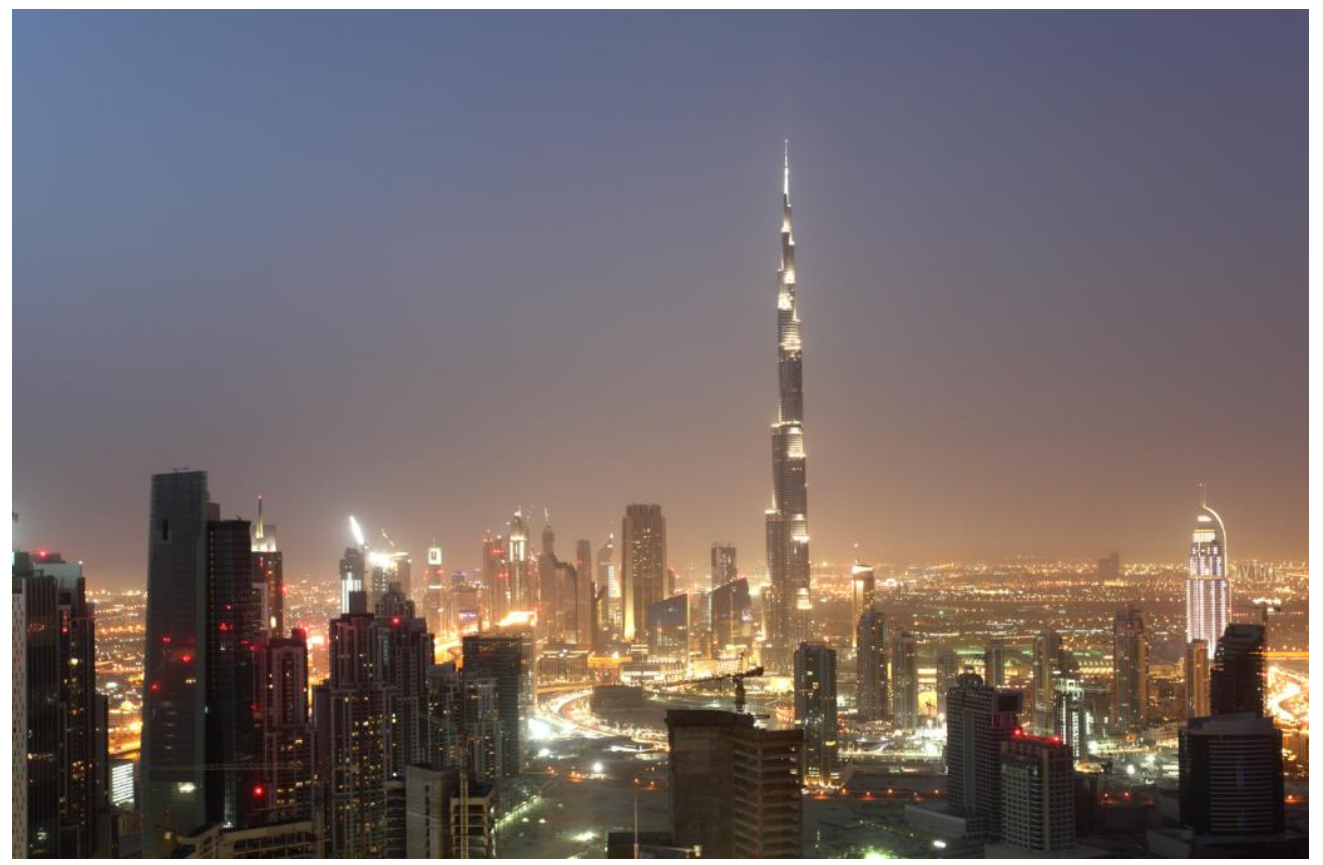

Fig 9 - Burj Khalifa, Dubai.

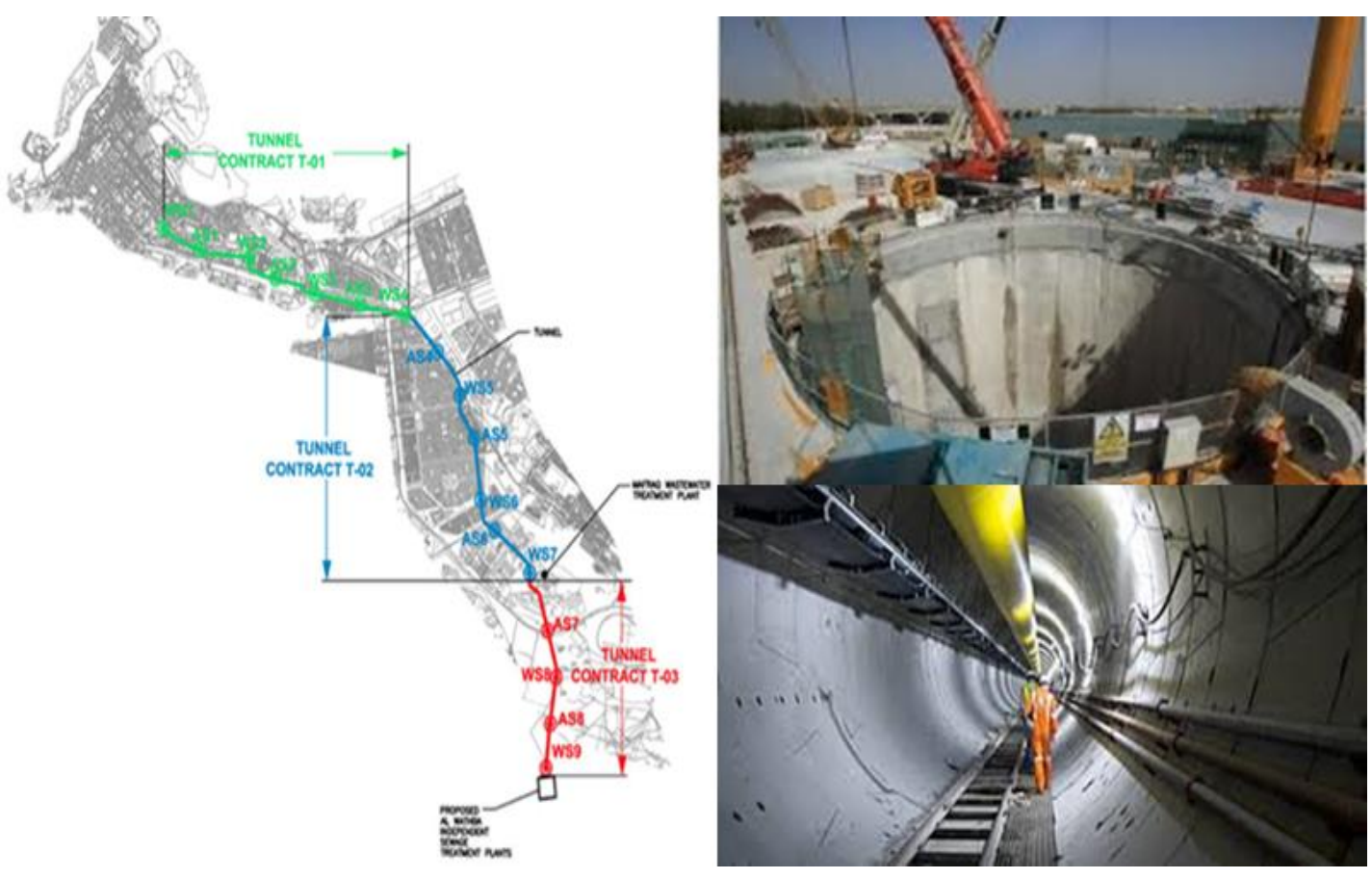

Fig 10 - STEP project, Abu Dhabi 


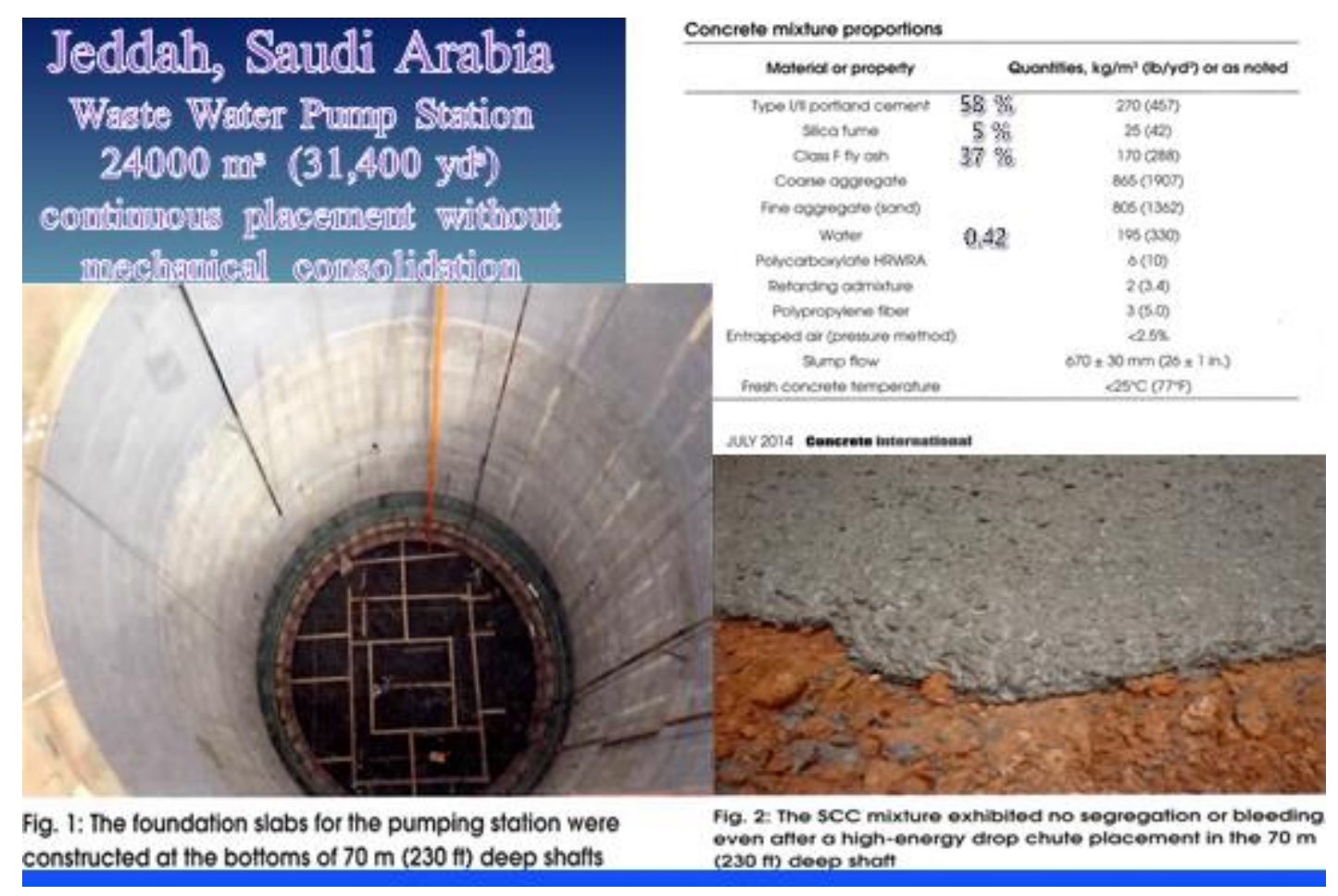

Fig. 11- Waste Water Pump Station, Jeddah, Saudi Arabia

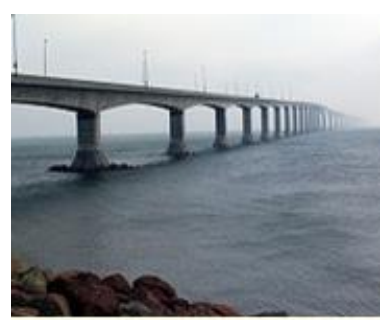

Confederation Bridge - Concrete Requirements : $F^{\prime} C=60 \mathrm{Mpa}(8,700 \mathrm{psi}), 25 \mathrm{Mpa}$ prior to freezing Air Content-maximum spacing factor $0.300 \mathrm{~mm}$ Maximum water permeability $10-14 \mathrm{~cm} / \mathrm{sec}$ Maximum RCP@91 days 1000 coulombs Chloride diffusivity 5 x 10-12 $\mathrm{m} 2 / \mathrm{sec}$

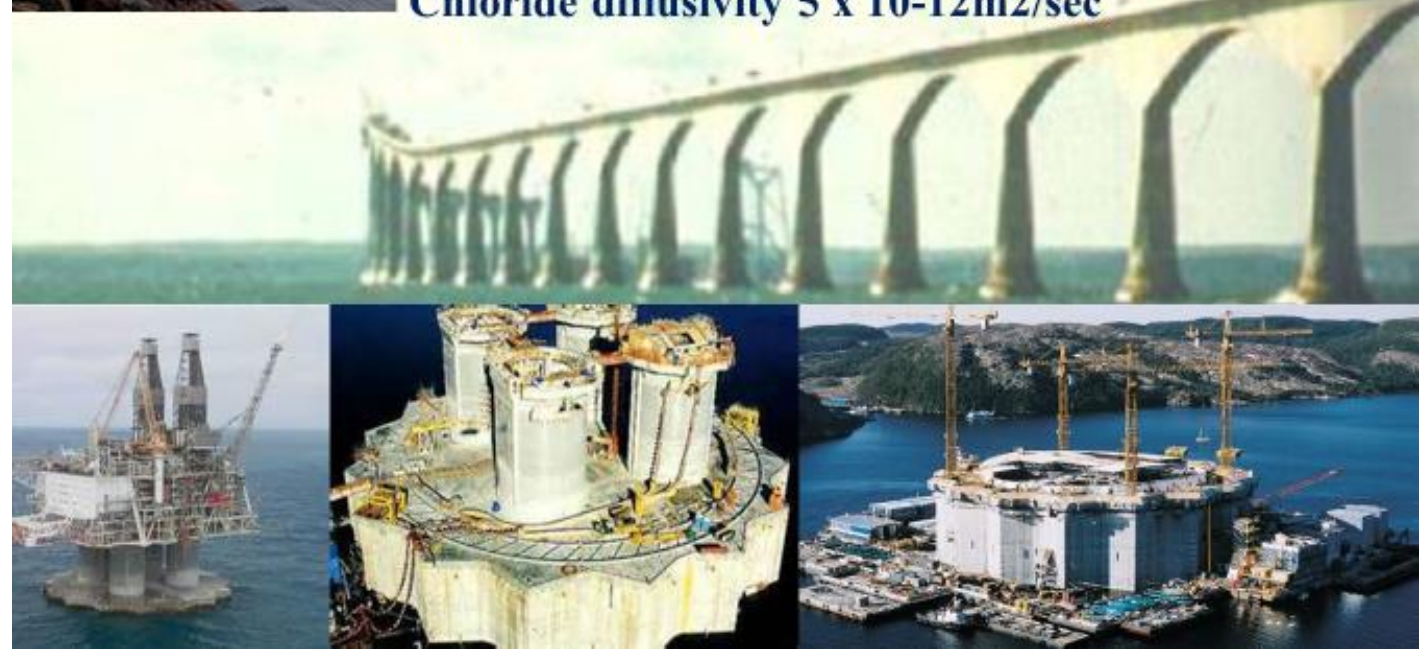

Figure 12 - Confederation Bridge, New Brunswick 


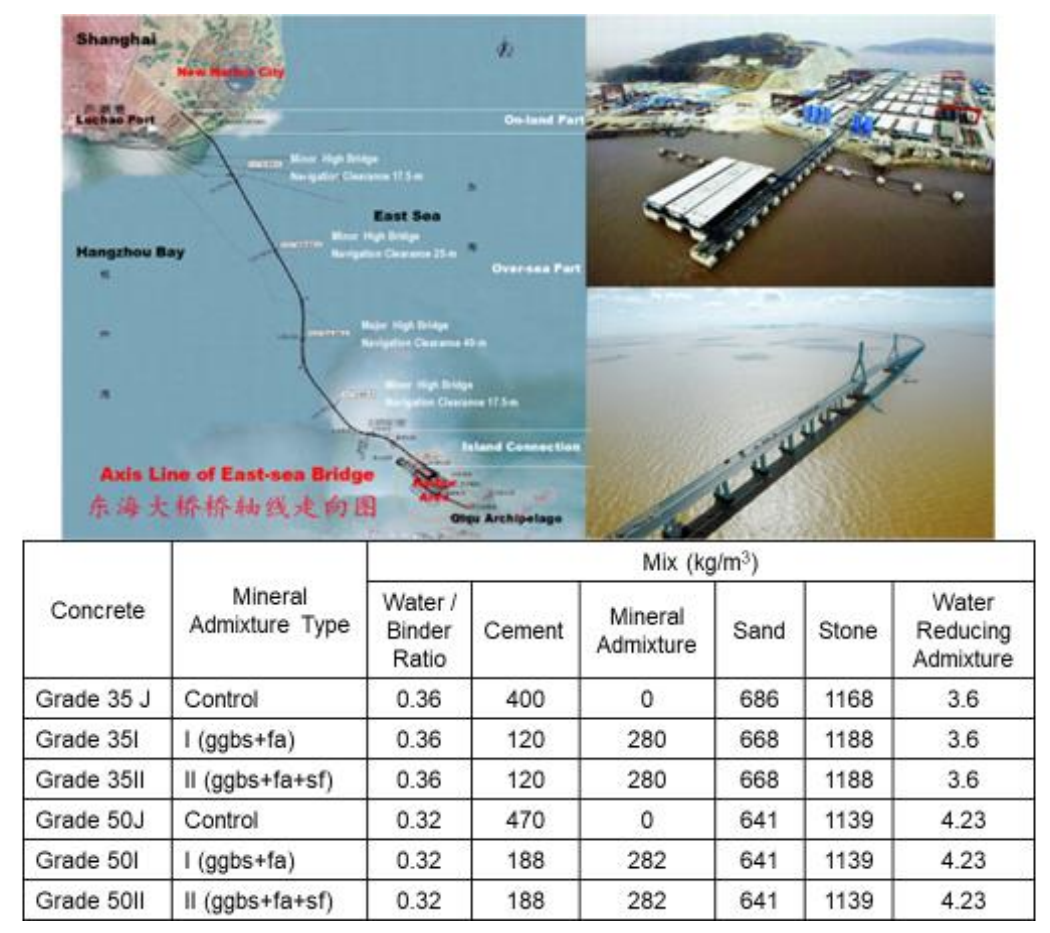

Figure 13 - The East Sea Bridge, Shanghai.

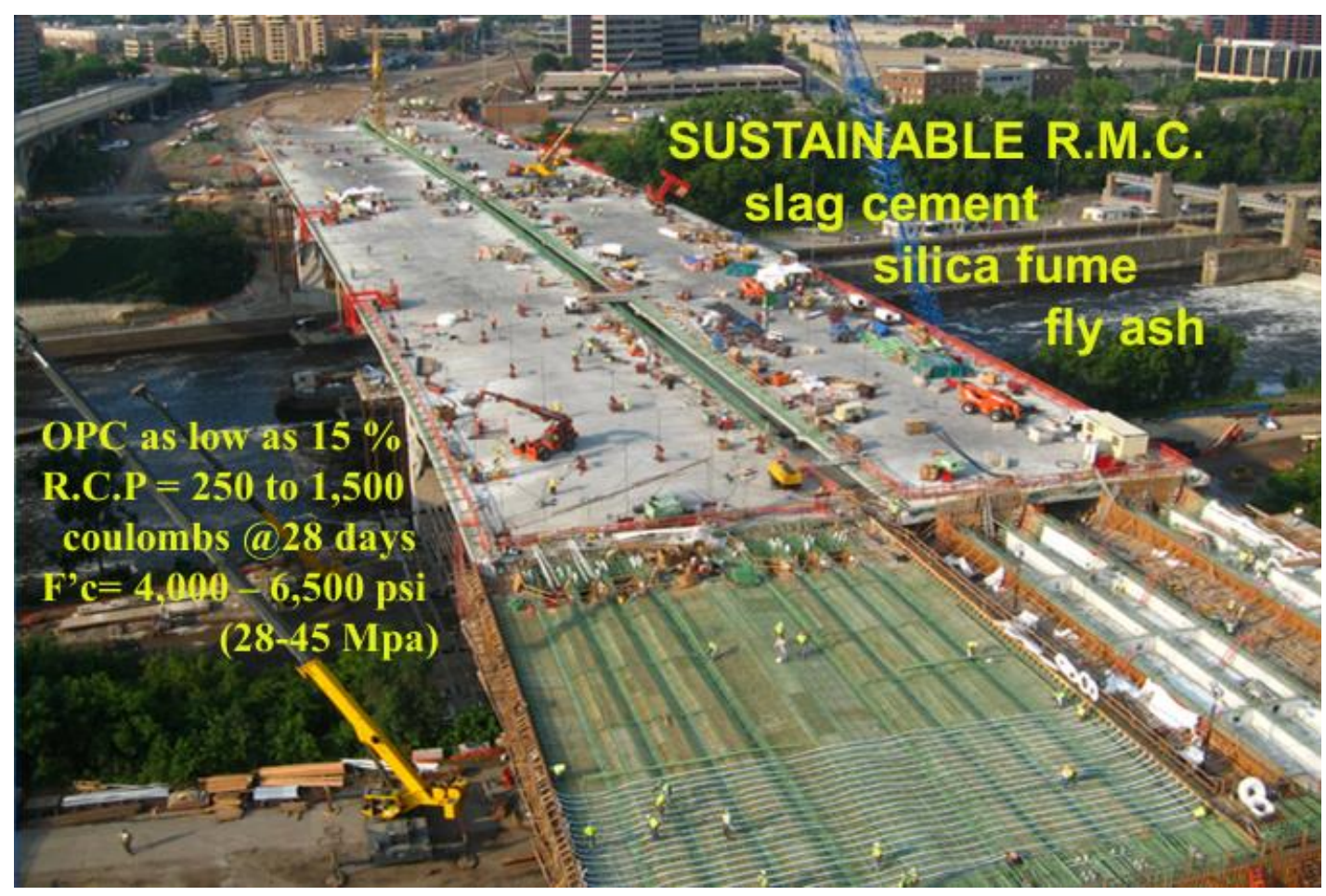

Figure 14 - I-35 W, Minneapolis 


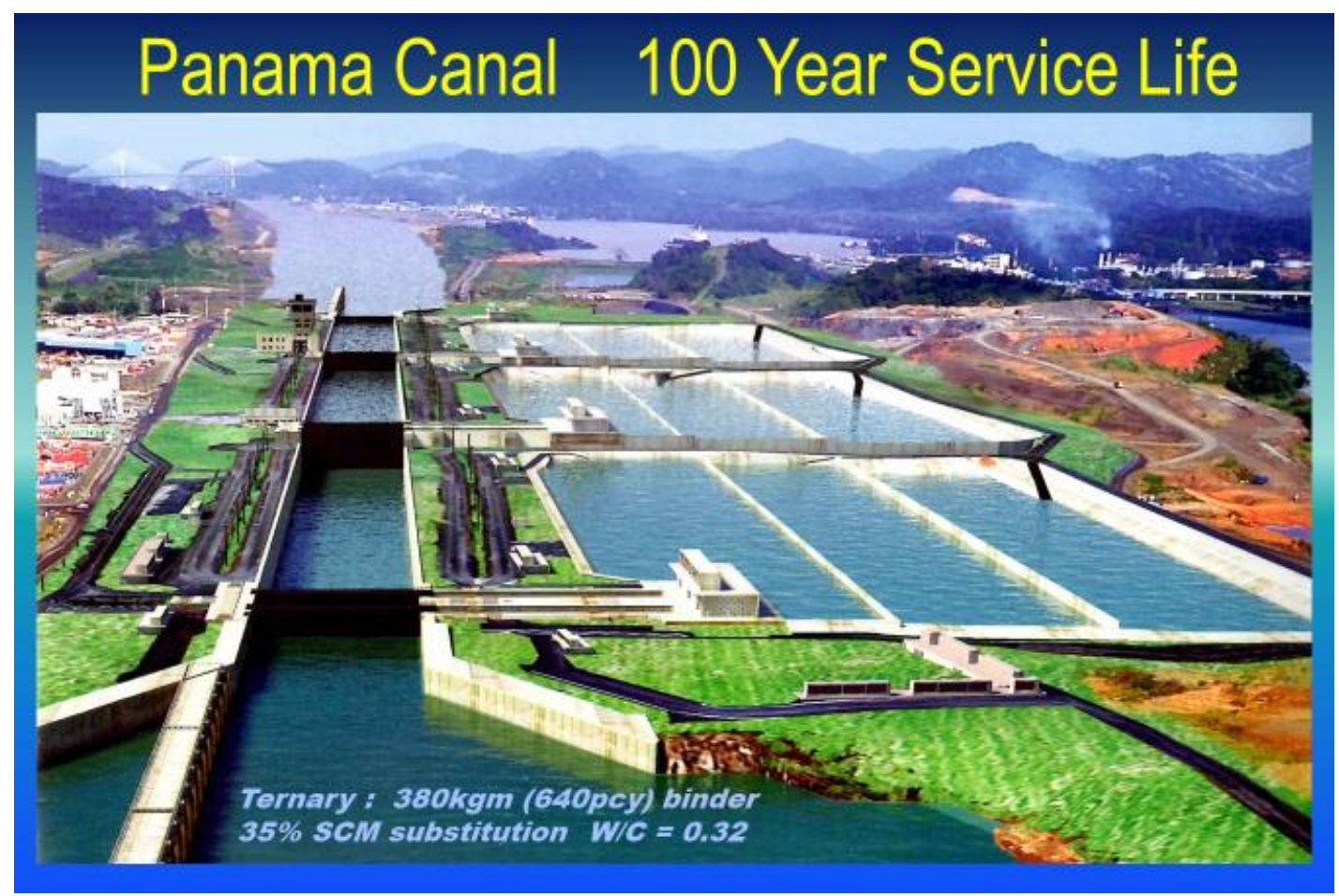

Figure 15 - The Panama Canal 